\title{
Growth and division mode plasticity by cell density in marine- derived black yeasts
}

\author{
Gohta Goshima ${ }^{1,2}$ \\ ${ }^{1}$ Sugashima Marine Biological Laboratory, Graduate School of Science, Nagoya \\ University, Sugashima, 429-63, Toba 517-0004, Japan \\ 2 Division of Biological Science, Graduate School of Science, Nagoya University, Furo- \\ cho, Chikusa-ku, Nagoya 464-8602, Japan \\ Email: goshima@bio.nagoya-u.ac.jp; Phone: +81 599-34-2216
}

\begin{abstract}
The diversity and ecological contribution of the fungus kingdom in the marine environment remain under-studied. A recent survey in the Atlantic (Woods Hole, MA, USA) brought to light the diversity and unique biological features of marine fungi. The study revealed that black yeast species undergo an unconventional cell division cycle, which has not been documented in conventional model yeast species such as Saccharomyces cerevisiae (budding yeast) and Schizosaccharomyces pombe (fission yeast). The prevalence of this unusual property is unknown. Inspired by the findings in Woods Hole, I collected and identified $>50$ marine fungi species across 40 genera from the ocean surface, sediment, and macroalgal surface in the Pacific (Sugashima, Toba, Japan). The Sugashima collection largely did not overlap with the Woods Hole collection and included several unidentifiable species, further illustrating the diversity of marine fungi. Three black yeast species were isolated, two of which were commonly found in Woods Hole (Aureobasidium pullulans, Hortaea werneckii). Surprisingly, I observed that their cell division mode was dependent on cell density, and the previously reported unconventional division mode was reproduced only at a certain cell density. For all three black yeast species, cells underwent filamentous growth with septations at low cell density and immediately formed buds at high cell density. At intermediate cell density, two black yeasts showed rod cells undergoing septation at the cell equator, in a manner similar to $S$. pombe. In contrast, all eight budding yeast species showed a consistent division pattern regardless of cell density. In five budding yeast species, the mother cell formed a single bud at a time at an apparently random site, similar to $S$. cerevisiae. The other three budding yeast species possessed a fixed budding site. This study illustrates the plastic nature of the growth/division mode of marine-derived black yeast.
\end{abstract}

\section{Introduction}

Understanding the habitats of marine organisms is important for understanding marine ecology. Much of this effort has been put on macro-organisms, such as fishes, benthic organisms, and invertebrates, as well as unicellular microorganisms such as algae and bacteria [1]. Relatively little attention has been paid to fungi, and little is known about their life cycle and physiology [2,3]. The genetics and cell biology of these organisms have been pioneered in a few terrestrial fungal systems, such as Saccharomyces cerevisiae, Schizosaccharomyces pombe, and Aspergillus nidulans [4-6]. An important step towards understanding the ecology of marine fungi is the identification of fungi in various locations. 
An interesting study was published in 2019, in which 35 fungi were collected from the sediment, surface ocean water, and benthic animals (corals, sponges) around Woods Hole, MA, USA. That study investigated the division pattern of several black yeast species via live imaging and found remarkable unconventional features in their cell division cycle [7]. For example, a single Hortaea werneckii cell always underwent fission during its first cell division, but the next division involved budding at $92 \%$ probability. This observation challenged the conventional view that a single cell division pattern is intrinsic to a yeast species; for example, $S$. pombe and $S$. cerevisiae always divide via fission or budding, respectively. In another striking example, more than $50 \%$ of Aureobasidium pullulans cells produced multiple rounds of simultaneous buds, which is never observed in S. cerevisiae [7]. From an ecological point of view, this study urges the necessity of further sampling and characterisation, as what has been reported to date is unlikely to be the full set of marine fungi in the ocean.

Inspired by [7], I collected free-living marine fungi in front of Nagoya University's Marine Biological Laboratory (NU-MBL) on Sugashima Island, Toba, Japan (Fig. 1A). The species were identified via DNA barcode sequencing, and the division pattern was observed for budding and black yeasts (no fission yeast was isolated). The collected species, or even genera, were only partially overlapped with [7], suggesting the existence of highly divergent fungal species in the ocean. Surprisingly, the division pattern of black yeasts ( $H$. werneckii, A. pullulans, and other unidentified species) was initially inconsistent with those previously reported in [7], and this enigma was solved through the observation of cell density-dependent alterations in their division patterns.

\section{Materials and methods}

\section{Isolation of marine fungi at NU-MBL}

Samples were collected for 8 days from $4^{\text {th }}$ March to $5^{\text {th }}$ June 2020, in which the majority were obtained on the $22^{\text {nd }}$ and $23^{\text {rd }}$ of April. The ocean water temperature was $15.5^{\circ} \mathrm{C}$ and the salinity was $34.9 \%$. This salinity indicates that there was no significant fresh water flow into this area from the large rivers in Ise Bay. Surface water samples were collected at the pier of the NU-MBL using a plastic bucket (Lat. $34^{\circ} 29^{\prime} 8^{\prime \prime} \mathrm{N}$, Long. $136^{\circ} 52^{\prime} 32^{\prime \prime} \mathrm{E}$ ) (Fig. 1B, green). One litre of seawater was filtered using a $0.45-\mu \mathrm{m}$ Millipore Stericup to obtain a $100 \times$ concentration. One millilitre of the concentrate was spread onto three types of media, which were similar to those used in [7]: YPD (10 g/L yeast extract, $10 \mathrm{~g} / \mathrm{L}$ peptone [Bacto tryptone], $20 \mathrm{~g} / \mathrm{L}$ glucose, $12 \mathrm{~g} / \mathrm{L}$ agar), malt medium $(20 \mathrm{~g} / \mathrm{L}$ malt extract, $6 \mathrm{~g} / \mathrm{L}$ tryptone, $20 \mathrm{~g} / \mathrm{L}$ glucose, $12 \mathrm{~g} / \mathrm{L}$ agar), and potato dextrose ( $24 \mathrm{~g} / \mathrm{L}$ potato dextrose broth, $12 \mathrm{~g} / \mathrm{L}$ agar). All species tested could grow on any medium; retrospectively, the preparation of three different media was not needed. Sediment samples were collected once by taking the mud at the bottom of the outside tank (Fig. 1C). Seaweeds were collected from the intertidal zone in front of the NU-MBL (Fig. 1B, magenta). Approximately $3 \mathrm{~cm} \times 3 \mathrm{~cm}$ fragments of seaweed were obtained, which were rinsed with semi-sterile seawater $(\sim 500 \mathrm{~mL})$ three times, followed by knife-cutting into small pieces and spreading onto a plate (Fig. 1D). All media were made with seawater at NU-MBL, which was pre-filtered with ADVANTEC filter paper \#2. Antibiotics were added to the medium to avoid bacterial growth $(20 \mu \mathrm{g} / \mathrm{mL}$ carbenicillin, $100 \mu \mathrm{g} / \mathrm{mL}$ chloramphenicol, $10 \mu \mathrm{g} / \mathrm{mL}$ tetracycline) [7]. All fungal isolates were stored at $-80^{\circ} \mathrm{C}$ in YPD medium containing 20\% glycerol. 
96 The ITS and NL sequences were sequenced for all strains using the primers listed in Table

971 [7]. If the species could not be determined through these two sequences, the $\beta$-tubulin

98 gene locus was amplified and sequenced. PCR was performed with the KOD-ONE kit 99 (TOYOBO) using a colony or the extracted genomic DNA as the template. DNA 100 extraction was performed by boiling a piece of fungal colony for 5 min in $0.25 \%$ SDS 101 followed by table-top centrifugation.

102

103

Table 1: Primers used in this study

\begin{tabular}{|l|l|l|}
\hline \multirow{2}{*}{ Locus } & Primer ID & Primer sequences \\
\hline \multirow{3}{*}{ NL1/4 } & $7577-$-ITS1 (fungi) & TCCGTAGGTGAACCTGCGG \\
\cline { 2 - 3 } & 7578 -ITS4 (fungi) & TCCTCCGCTTATTGATATGC \\
\cline { 2 - 3 } & $7579-$-NL1 (fungi) & GCATATCAATAAGCGGAGGAAAAG \\
\hline \multirow{4}{*}{$\beta$-Tubulin } & $7580-$ NL4 (fungi) & GGTCCGTGTTTCAAGACGG \\
\cline { 2 - 3 } & $7607-$ fungal-b-tub-Fw1 & CGTGACAGGGTAACCAAATTGGTG \\
\cline { 2 - 3 } & 7608 -fungal-b-tub-Fw2 & GAGCCCGGTACCATGGACG \\
\cline { 2 - 3 } & 7609 -fungal-b-tub-Rv1 & GGTGATCTGGAAACCCTGGAGG \\
\cline { 2 - 3 } & 7610 -fungal-b-tub-Rv2 & CCCATACCGGCACCGGTACC \\
\hline
\end{tabular}

\section{Species identification}

Sequence homology was determined using the BLASTN program. If both ITS and NL sequences were perfectly matched to a single species, the fungal isolate was concluded to be the species. If not, the $\beta$-tubulin sequences were also used. In some cases, either the ITS or NL sequences had a $100 \%$ match to a certain species, whereas the other did not show an exact match. When the mismatch was less than $3 \mathrm{bp}$, the fungal isolate was likely the species with a slight strain-specific sequence variation, whereas a $>3 \mathrm{bp}$ mismatch in two or three barcodes led to the assignment of possible novel species or genera. All the barcode sequences are presented in Table S1.

\section{Live microscopy}

Initially, cells grown on the YPD plate were directly inoculated into YPD liquid medium in an 8-well glass-bottom dish (Iwaki). However, the division modes were not consistent between experiments for some species. Therefore, cells were grown in a YPD liquid medium until saturation and inoculated into an 8-well plate after cell counting (300 $\mu \mathrm{L}$ culture volume). Note that this liquid-based imaging condition is different from that in [7], in which agar pads were used. The growths of $10^{3}, 10^{4}, 10^{5}$, and $>10^{5}$ cells were compared for black yeasts. Transmission light imaging was carried out at $23{ }^{\circ} \mathrm{C}$ with a Nikon inverted microscope (Ti) with a 40×0.95 NA lens (Plan Apo) and a Zyla CMOS camera (Andor). The brightness and contrast of the obtained images were adjusted using FIJI software. For DNA imaging of Hortaea werneckii, cells were cultured with a more transparent medium. Synthetic minimal medium, similar to what was used for Aspergillus nidulans, was made with sea water $\left(6 \mathrm{~g} / \mathrm{L} \mathrm{NaNO}_{3}, 0.52 \mathrm{~g} / \mathrm{L} \mathrm{KCl}, 1.52 \mathrm{~g} / \mathrm{L} \mathrm{KH}_{2} \mathrm{PO}_{4}, 10\right.$ $\mathrm{g} / \mathrm{L}$ glucose, $1.5 \mathrm{~mL}$ trace elements, $10 \mathrm{mg} / \mathrm{L}$ biotin, $0.25 \mathrm{~g} / \mathrm{L} \mathrm{MgSO}_{4}, \mathrm{pH}=6.5$ [adjusted with $\mathrm{NaOH}$ ]) [8]. Hoechst 33342 was added at $3-6 \mu \mathrm{g} / \mathrm{mL}$ (final). DNA imaging was performed with another Nikon inverted microscope (Ti2) attached to a 100× 1.40 NA lens, 
131 a 405-nm laser, CSU-10 spinning-disc confocal unit, and the CMOS camera Zyla (at

$13223^{\circ} \mathrm{C}$ ). The time intervals used were mostly $2 \mathrm{~min}$, but sometimes $2.5 \mathrm{~min}$ or $5 \mathrm{~min}$ was

133 used. The microscopes were controlled using NIS Elements software (Nikon).

134

135

136

137

138

139

140

141

142

143

144

145

146

147

148

149

150

\section{Results and Discussion}

\section{Isolation of fungi at the Sugashima marine laboratory}

Fungi were isolated from three sources: surface ocean sea water near the beach (Fig. 1B, green), an outdoor tank that has various benthic animals and seaweeds (circulated surface water and sediment; Fig. 1C), and sliced seaweeds (each $\sim 3 \mathrm{~cm}$ ) that were collected in the intertidal zone in front of the laboratory (Fig. 1B [magenta], D). The sediment was most enriched with fungi (Fig. 1E; $200 \mu \mathrm{L}$ sediment). Fungal colonies were obtained from $100 \mathrm{~mL}$ surface sea water, and $7.5 \pm 8.5$ fungal colonies were obtained $(\mathrm{n}=6)$, whereas seaweeds were a more abundant source of fungi $(25 \pm 26$ colonies isolated from a $\sim 3 \mathrm{~cm}$ piece of seaweed body $[n=10])$. However, based on colony colour, it was deduced that many colonies were derived from the same species. In total, 74 colonies were regrown on separate plates (four examples are shown in Fig. 1F), and two or three barcode regions were sequenced. For some clones, the species or even genera could not be identified because of the high deviation of the barcode sequences from the known sequences registered in the database (named with "sp" or described as "unclear" in Table 2). The total number of species identified was 50-65, depending on whether several clones (e.g. Cladosporium) were considered to be the same species (Table 2).

\section{Comparison with the Woods Hole collection}

There were considerable differences between the current collection at Sugashima and what was identified around Woods Hole [7] (Table 2, right column). Only six species were isolated in both studies (Aureobasidium pullulans, Cladosporium halotolerans, Hortaea werneckii, Metschnikowia bicuspidate, Meyerozyma guilliermondii, and 159 Parengyodontium album). At the genus level, only seven genera were common 160 (Aspergillus, Candida, Epicoccum, Filobasidium, Penicillium, Rhodotorula, and 161 Trichoderma), while other genera were uniquely isolated in either location: 27 from 162 Sugashima (Alternaria, Arthopyrenia, Arthrinium, Cystobasidium, Diaporthe, Didymella, 163 Fusarium, Kluyveromyces, Letendraea, Leucosporidium, Microdochium, Neoascochyta, 164 Neopestalotiopsis, Paraboeremia, Paradendryphiella, Pestalotiopsis, Phacidium, Phoma, 165 Pyrenochaetopsis, Simplicillium, Sphaerulina, Umbelopsis, Ustilago, and four unclear 166 genera), and six from Woods Hole (Apiotrichum, Cadophora, Cryptococcus, Exophiala, 167 Knufia, Phaeotheca). While this discrepancy may partly stem from seasonal or regional 168 differences, it more likely reflects the limited coverage of fungi in both studies. My survey 169 agrees with the current view that many more species exist in the ocean [3].

\section{Budding yeast species with fixed and variable bud positions}

172 Fifteen fungal species produced yeast-like colonies on culture plates (Fig. 1F, second 173 image). Live imaging was performed for these species at least thrice at different cell 174 densities. Five of them turned out to have S. cerevisiae-like budding-growth cycles, where 175 a daughter cell emerged from the round-shaped mother cell and a mother cell can produce 176 a second daughter at other sites than the previous one (Candida sake, Kluyveromyces 177 nonfermentans, Metschnikowia bicuspidate, Meyerozyma guilliermondii, Rhodotorula 
$s p$.) (Fig. 2A, Video 1). Interestingly, the budding sites of three other yeasts were fixed, although the mother cell had a nearly round shape (Cystobasidium slooffiae, Filobasidium magnum, Filobasidium sp.) (Fig. 2B, Video 1). Four other fungi were rod-shaped, in which fission and/or budding were observed (Leucosporidium intermedium, Ustilago sp., Sphaerulina rhabdoclinis, Sphaerulina sp.) (Video 2).

\section{Cell density-dependent division pattern alteration in the black yeast $\boldsymbol{A}$. pullulans}

The remaining three fungi that formed yeast-like colonies produced black or brown pigment. Two of them have been extensively studied by [7]: A. pullulans (Fig. 3A) and H. werneckii (Fig. 4A). A. pullulans in [7] had a round shape and showed multiple buds at one site. However, in my first few imaging attempts, such a characteristic division pattern was never observed. Instead, they first grew as filaments, and later produced multiple buds from many locations on the filament. In the course of repetitive imaging, it was noticed that a division pattern closer to that described in [7] could be obtained when the initial cell density was increased. To test the possibility that the division pattern is density-dependent, a 10-fold dilution series of the strain was prepared for imaging (relative cell densities: $\times 1, \times 10, \times 100$, and $\times 1000$ ). When the initial cell density was low, a single cell first elongated with occasional septation, followed by multiple budding from the elongated cell filament $(100 \%, n=50)($ Fig. 3B, D, Video 3). The higher the cell density, the faster the bud emerged (Fig. 3C). Immediate budding without extensive mother cell elongation or septation was observed only when the initial cell density was high (Fig. 3B, 19 out of 30 cells). However, the majority of the cells (14/19) showed buds at both poles of the mother cell (Fig. 3E) rather than produced buds from the same pole, as reported in [7] (5/19) (Fig. 3F). Thus, this black yeast species showed division pattern variation depending on the cell density.

It should be noted that the identity of the bud is unknown. An earlier study involving immunofluorescence microscopy of microtubules and actin interpreted that the buds were conidia (asexual spores) [9]. This is a possible interpretation.

\section{Cell density-dependent division pattern alteration in the black yeast $\boldsymbol{H}$. werneckii}

Two clones of $H$. werneckii were isolated, and their colony growth rates were slightly different (Fig. 4A). The barcode sequences had high similarity but were not identical (1 $\mathrm{bp}$ mismatch). These were interpreted as natural variants of the same species. Imaging of these clones initially produced puzzling results: the reported characteristic division pattern - a single cell almost always undergoes fission, followed by budding [7] - was rarely observed. To test the possibility that, similar to $A$. basidium, the initial cell density might have affected the division pattern, the number of inoculated cells was varied $(\times 1$, $\times 10, \times 100, \times 300$ ). The initial cell numbers dramatically affected the mode of the first few cell divisions in both isolates (Fig. 4B presents the result of NU28; Video 4). Multiple rounds of septation were observed when cell density was low and multiple budding occurred hours later (Fig. 4B, D). The higher the cell density, the earlier the bud emerged (Fig. 4C). In contrast, the reported mode of division - fission followed by budding - was predominantly observed when the cell density was high (Fig. 4B, E). However, cells that formed buds without fission were also observed, which was not reported in [7] (Fig. 4B, F). Thus, the division pattern variability of our $H$. werneckii strain was similar to that of A. pullulans. 
225

226

227

228

229

230

231

232

233

234

235

236

237

238

239

240

241

242

243

244

245

246

247

248

249

250

251

252

253

254

255

256

257

258

259

260

261

262

263

264

265

266

267

268

269

270

271

\section{Cell density-dependent division pattern alteration in an unidentified black yeast species}

In the present study, another yeast strain (NU30) formed dark brown-coloured colonies on the plate (Fig. 5A). The barcode sequences did not perfectly match any registered species; because the mismatch was large, the name of this yeast could not be determined. To reveal its growth/division pattern and test if it was altered depending on the initial cell density, time-lapse imaging was conducted at four different initial cell densities $(\times 1, \times 10$, $\times 100$, and $\times 700$ ). The cell division pattern observed was remarkably similar to that of $H$. werneckii (Fig. 5B-F, Video 5). Budding occurred after multiple septations when the initial cell density was low, whereas a mother cell, without cell septation, produced multiple buds sequentially from the same site (blue and magenta arrows) when the initial cell density was high (Fig. 5E, F).

\section{Nuclear segregation scales with cell length in $H$. werneckii}

In the model budding yeast $S$. cerevisiae, budding starts at the G1/S transition of the cell cycle, and nuclear division takes place when the bud reaches a certain size [10]. In $S$. pombe, the nucleus is kept in the centre of the cell during interphase (mostly G2 phase), then mitotic commitment occurs when the cell reaches a certain length $(\sim 14 \mu \mathrm{m})$ [11]. In both cases, cell division (septation) occurs immediately after nuclear division, producing daughter cells that have an identical shape to the mother. In contrast, in A. nidulans and Ashbya gossypii, the model filamentous fungi, multiple nuclear divisions take place without septation in the tip-growing cells, resulting in the production of multinucleated cells $[12,13]$. I was curious whether nuclear and cell divisions were coupled in the above three black yeast species, whose division pattern was flexible.

To follow nuclear division and septation/budding in live cells, their nuclei were stained with Hoechst 33342, which is known to be permeable in many cell types, including $S$. pombe [14]. However, staining and live imaging of $A$. pullulans and NU30 were not successful. In contrast, $H$. werneckii was stainable, and its nuclear dynamics was observable in real time (Fig. 6, Video 6, 7). Therefore, time-lapse imaging with Hoechst 33342 using a spinning-disc confocal microscope was performed for $H$. werneckii.

In the budding type of mitosis shown in Fig. 6A, which prevailed when the cell density was high, nuclear separation occurred when the bud size reached $60 \pm 11 \%( \pm$ $\mathrm{SD})$ of the mother $(\mathrm{n}=30)$. The nucleus was positioned in the mother, slightly on the bud neck side at the time of chromosome condensation (i.e. mitotic entry) ( $44 \pm 6 \%$ position from the bud neck). Sister chromatid separation occurred in the mother, and one of the sister chromatids moved into the bud. Kymograph analysis indicated that the sister chromatid motility relative to the cell edge was asymmetric (Fig. 6A, bottom): the sister on the bud side moved much longer distances, whereas the sister in the mother moved much less or sometimes showed bud-oriented movement. The maximum distance between sister chromatids was $9.4 \pm 1.1 \mu \mathrm{m}$, which was comparable to the mother cell length $(9.2 \pm 1.0 \mu \mathrm{m})$ and was $36 \%$ shorter than the entire cell length (i.e., daughter + mother length). These results suggested that the anaphase spindle was motile in the cell. The mitotic duration (chromosome condensation to anaphase onset) was $14 \pm 7 \mathrm{~min}$. Septation, which was indicated by a straight line of the Hoechst dye at the bud neck, was completed $16 \pm 6$ min after sister chromatid separation.

In the fission type of mitosis shown in Fig. 6B, the nucleus was positioned near the centre of the cell at the time of chromosome condensation $(50 \pm 5 \%$ position along the 
cell axis, $\mathrm{n}=20$ ). After $16 \pm 3 \mathrm{~min}$, the sister chromatids were separated. Unlike in $S$. pombe, chromosome segregation did not always occur symmetrically (232-236 min time point in Video 6) and the chromatids rarely reached the cell edge (maximum sister chromatid distance was $5.6 \pm 0.5 \mu \mathrm{m}$, which was $54 \pm 5 \%$ of cell length) (Fig. $6 \mathrm{~B}$, bottom). Septation was completed in the middle of the cell at $29 \pm 4$ min after sister chromatid separation.

In the tip-growing cells, which were observed at low cell density, a single nucleus was detected, and it moved apically during tip growth, contrary to the multiple nuclei in A. nidulans or A. gossypii (Fig. 6C and 6D; flare-like structures were also stained by Hoechst 33342). Therefore, the nucleus stayed near the centre of the cell $(46 \pm 5 \%$ position from the tip at mitotic entry, $\mathrm{n}=15)$. The cell length was quite variable at the time of chromosome condensation $(34 \pm 10 \mu \mathrm{m}, \pm \mathrm{SD}, \mathrm{n}=15)$; in some cases, it reached $>40 \mu \mathrm{m}$, which was four times longer than the rod-shaped or budding cells described above. Mitotic duration was shorter than that in other types $(9 \pm 1 \mathrm{~min}, \mathrm{n}=9)$. Sister chromatids moved longer distances $(52 \pm 7 \%$ of the cell length, $\mathrm{n}=14)$ and septation occurred in the middle of the two nuclei at $22 \pm 4.5 \mathrm{~min}(\mathrm{n}=8)$ after sister chromatid separation. However, the middle part was motile during anaphase, implying that the anaphase spindle was motile in the cell. Consequently, the chromosome position at metaphase was not always consistent with the septation position (Fig. 6D).

Thus, despite variations in cell size and geometry (rod, filament, bud), septation was coupled with nuclear division. However, the segregating distance of sister chromatids varied significantly, scaling with the cell length and shape.

\section{Conclusions}

Two major conclusions can be drawn from this study. First, a very limited local survey has increased the list of marine-derived fungi, illustrating their diversity in the ocean. The species could not be determined for several fungi, suggesting that they might represent undescribed species. More comprehensive sampling and taxonomic analyses are needed to further expand the list of fungi from the ocean. Second, the collected black yeast species changed their division mode depending on the cell density. This plasticity may be beneficial for them, particularly when they reside on the surfaces of animals and macroalgae. Filamentous growth with branching is an excellent means to explore unoccupied areas, whereas budding in a crowded environment allows the clone to be released to the free water and translocated to other animal/algae surfaces. This property somewhat resembles that of filamentous fungi such as Aspergillus; they exhibited 2D hyphal growth, followed by conidia (asexual spores) release [15]. Switching between yeast-like budding and hyphal growth has also been reported for the pathogenic fungus Candida albicans $[16,17]$. However, the filament was curved and area exploration was not optimised for $H$. werneckii and NU30; hence, the advantage of this growth/division mode remains unclear. Combined with this and previous studies [7], all five observed black yeast species showed at least two growth/division patterns. Elucidating the chemical and/or physical cues that trigger the division mode alteration and the prevalence of plasticity in marine fungi would be interesting topics for future research.

\section{Acknowledgements}

I am grateful to Tomoya Edzuka and Maki Shirae-Kurabayashi for seaweed collection, Masahiro Suzuki (Kobe University) for help with seaweed identification, Masashi 
319 Fukuoka for daily temperature and salinity measurements, Naoto Jimi for helpful

320 comments on taxonomy, and Amy Gladfelter (Marine Biological Laboratory, Woods

321 Hole/University of North Carolina) for the introduction to marine fungal biology and

322 encouraging sample collection on the Japanese coast. This work was supported by JSPS

323 KAKENHI (17H06471, 18KK0202).

324

325

326

327

328

329

330

331

332

333

334

335

336

337

338

339

340

\section{References}

1. OBIS (ocean biodiversity information system). https://obis.org/.

2. Gladfelter, A.S., James, T.Y., and Amend, A.S. (2019). Marine fungi. Curr Biol 29, R191-R195.

3. Amend, A., Burgaud, G., Cunliffe, M., Edgcomb, V.P., Ettinger, C.L., Gutierrez, M.H., Heitman, J., Hom, E.F.Y., Ianiri, G., Jones, A.C., et al. (2019). Fungi in the Marine Environment: Open Questions and Unsolved Problems. mBio 10.

4. Nurse, P., and Hayles, J. (2019). Using genetics to understand biology. Heredity (Edinb) 123, 4-13.

5. Osmani, S.A., and Mirabito, P.M. (2004). The early impact of genetics on our understanding of cell cycle regulation in Aspergillus nidulans. Fungal Genet Biol 41, 401-410.

6. Feyder, S., De Craene, J.O., Bar, S., Bertazzi, D.L., and Friant, S. (2015). Membrane trafficking in the yeast Saccharomyces cerevisiae model. Int J Mol Sci $16,1509-1525$.

7. Mitchison-Field, L.M.Y., Vargas-Muniz, J.M., Stormo, B.M., Vogt, E.J.D., Van Dierdonck, S., Pelletier, J.F., Ehrlich, C., Lew, D.J., Field, C.M., and Gladfelter, A.S. (2019). Unconventional Cell Division Cycles from Marine-Derived Yeasts. Curr Biol 29, 3439-3456 e3435.

8. Edzuka, T., Yamada, L., Kanamaru, K., Sawada, H., and Goshima, G. (2014). Identification of the augmin complex in the filamentous fungus Aspergillus nidulans. PLoS One 9, e101471.

9. Kopecka, M., Gabriel, M., Takeo, K., Yamaguchi, M., Svoboda, A., and Hata, K. (2003). Analysis of microtubules and F-actin structures in hyphae and conidia development of the opportunistic human pathogenic black yeast Aureobasidium pullulans. Microbiology (Reading) 149, 865-876.

10. Juanes, M.A., and Piatti, S. (2016). The final cut: cell polarity meets cytokinesis at the bud neck in S. cerevisiae. Cell Mol Life Sci 73, 3115-3136.

11. Wood, E., and Nurse, P. (2015). Sizing up to divide: mitotic cell-size control in fission yeast. Annu Rev Cell Dev Biol 31, 11-29.

12. Gladfelter, A.S., Hungerbuehler, A.K., and Philippsen, P. (2006). Asynchronous nuclear division cycles in multinucleated cells. J Cell Biol 172, 347-362.

13. Fischer, R. (1999). Nuclear movement in filamentous fungi. FEMS Microbiol Rev 23, 39-68.

14. Haraguchi, T., Ding, D.Q., Yamamoto, A., Kaneda, T., Koujin, T., and Hiraoka, Y. (1999). Multiple-color fluorescence imaging of chromosomes and microtubules in living cells. Cell Struct Funct 24, 291-298.

15. Adams, T.H., Wieser, J.K., and Yu, J.H. (1998). Asexual sporulation in Aspergillus nidulans. Microbiol Mol Biol Rev 62, 35-54. 
16. Merson-Davies, L.A., and Odds, F.C. (1989). A morphology index for characterization of cell shape in Candida albicans. J Gen Microbiol 135, 31433152.

17. Sudbery, P., Gow, N., and Berman, J. (2004). The distinct morphogenic states of Candida albicans. Trends Microbiol 12, 317-324.

\section{Supplementary video legends}

\section{Video 1. Cell division of marine-derived budding yeast}

Time-lapse imaging of two budding yeast species (5-min intervals). The budding site is variable (left) or fixed (right) depending on the species.

Video 2. Cell division of rod-shaped fungi Ustilago sp., Leucosporidium intermedium, and Sphaerulina rhabdoclinis

Time-lapse imaging of three fungi that have a rod shape and form yeast-like colonies on the plate (5-min interval).

\section{Video 3. Cell division of the black yeast Aureobasidium pullulans}

Live imaging of Aureobassidium pullans (NU67) at four different initial cell densities. Images were acquired every $15 \mathrm{~min}$.

\section{Video 4. Cell division of the black yeast Hortaea werneckii}

Live imaging of Hortaea werneckii (NU28) at three different initial cell densities (lower left, high: upper left, medium: right, low). Images were acquired every $15 \mathrm{~min}$.

\section{Video 5. Cell division of an unidentified black yeast species}

Live imaging of NU30 (unnamed) at three different initial cell densities (lower left, high: upper left, medium: right, low). Images were acquired every $15 \mathrm{~min}$.

Video 6. Nuclear dynamics in the black yeast Hortaea werneckii-budding and fission Live imaging of chromosomes in Hortaea werneckii (NU28) during budding- and fissiontype mitosis. Images were acquired every $2 \mathrm{~min}$.

\section{Video 7. Nuclear dynamics in the black yeast Hortaea werneckii-growing tip}

Live imaging of chromosomes in Hortaea werneckii (NU28) during mitosis of tipgrowing cells. Images were acquired every $5 \mathrm{~min}$. Note that flare-like structures are also stained. 
405 Table 2. List of marine fungi identified in this study (alphabetical order)

\begin{tabular}{|c|c|c|c|c|c|}
\hline ID & Species & Site & Collection type & $* 1$ & $* 2$ \\
\hline NU15 & Alternaria chlamydospora & outdoor tank & Bryopsis & & n.d. \\
\hline NU14 & Arthopyrenia salicis & rope at pier & Ulva & & n.d. \\
\hline NU29 & Arthrinium arundinis & outdoor tank & surface water & & n.d. \\
\hline NU11 & Aspergillus protuberus & rope at pier & Undaria & & n.d. \\
\hline NU47 & Aspergillus tabacinus & intertidal zone & Lomentaria & & n.d. \\
\hline NU33 & Aspergillus versicolor & water at pier tip & surface water & & n.d. \\
\hline NU41 & Aspergillus westerdijkiae & intertidal zone & Undaria & & n.d. \\
\hline NU67 & Aureobasidium pullulans & water at pier tip & surface water & & \\
\hline NU45 & Candida sake & intertidal zone & Codium & & \\
\hline NU56 & Cladosporium halotolerans & intertidal zone & Lomentaria & & n.d. \\
\hline NU19 & Cladosporium sp. (1) & outdoor tank & surface water & & n.d. \\
\hline NU22 & Cladosporium sp. (2) & outdoor tank & surface water & & n.d. \\
\hline NU26 & Cladosporium sp. (3) & outdoor tank & surface water & & n.d. \\
\hline NU13 & Cladosporium sp. (4) & outdoor tank & Codium & & n.d. \\
\hline NU34 & Cladosporium sp. (5) & intertidal zone & Lomentaria & & n.d. \\
\hline NU4 & Cladosporium sp. (6) & outdoor tank & sediment & & n.d. \\
\hline NU6 & Cystobasidium slooffiae & rope at pier & Undaria & & \\
\hline NU59 & Diaporthe sp. & intertidal zone & Spatoglossum & & n.d. \\
\hline NU40 & Didymella heteroderae & intertidal zone & Ulva & & n.d. \\
\hline NU64 & Didymella sp. & intertidal zone & Codium & & n.d. \\
\hline NU39 & $\begin{array}{l}\text { Epicoccum latusicollum (or E. } \\
\text { sorghinum) }\end{array}$ & intertidal zone & Champia & & n.d. \\
\hline NU49 & Filobasidium magnum & intertidal zone & Ulva & & \\
\hline NU24 & $\begin{array}{l}\text { Filobasidium sp. } \\
\text { (likely unreported species) }\end{array}$ & outdoor tank & surface water & & \\
\hline NU37 & Fusarium incarnatum & intertidal zone & Champia & & n.d. \\
\hline NU28 & Hortaea werneckii (1) & outdoor tank & surface water & & \\
\hline NU32 & Hortaea werneckii (2) & water at pier tip & surface water & & \\
\hline NU2 & Kluyveromyces nonfermentans & outdoor tank & sediment & & \\
\hline NU42 & Letendraea sp.(1) & intertidal zone & Undaria & & n.d. \\
\hline NU54 & Letendraea sp.(2) & intertidal zone & Codium & & n.d. \\
\hline
\end{tabular}




\begin{tabular}{|c|c|c|c|c|}
\hline NU61 & Leucosporidium intermedium & intertidal zone & Undaria & \\
\hline NU27 & Metschnikowia bicuspidata & outdoor tank & surface water & \\
\hline NU73 & Meyerozyma guilliermondii & water at pier tip & surface water & \\
\hline NU69 & Microdochium sp. & water at pier tip & surface water & n.d. \\
\hline NU65 & Neoascochyta paspali & intertidal zone & Laurencia-like & n.d. \\
\hline NU46 & Neopestalotiopsis clavispora & intertidal zone & Lomentaria & n.d. \\
\hline NU48 & Neopestalotiopsis sp. & intertidal zone & Champia & n.d. \\
\hline NU21 & Paraboeremia putaminum & outdoor tank & surface water & n.d. \\
\hline NU57 & Paradendryphiella arenariae & intertidal zone & Champia & n.d. \\
\hline NU18 & Parengyodontium album & outdoor tank & Dasya & n.d. \\
\hline NU36 & Penicillium brasilianum & intertidal zone & Grateloupia & n.d. \\
\hline NU38 & Penicillium brevicompactum & intertidal zone & Champia & n.d. \\
\hline NU52 & Penicillium janczewskii & intertidal zone & Fushitsunagia & n.d. \\
\hline NU20 & Penicillium citrinum & outdoor tank & surface water & n.d. \\
\hline NU5 & Penicillium concentricum & outdoor tank & sediment & n.d. \\
\hline NU71 & Penicillium glandicola & intertidal zone & Colpomenia & n.d. \\
\hline NU55 & Penicillium lenticrescens & intertidal zone & Laurencia-like & n.d. \\
\hline NU51 & Penicillium magnielliptisporum & intertidal zone & Fushitsunagia & n.d. \\
\hline NU3 & Penicillium marinum & outdoor tank & sediment & n.d. \\
\hline NU53 & $\begin{array}{l}\text { Penicillium sp. } \\
\text { (could be P. sclerotiorum or P. } \\
\text { multicolor) }\end{array}$ & intertidal zone & Colpomenia & n.d. \\
\hline NU62 & Penicillium sp. (or P. alogum) & intertidal zone & Fushitsunagia & n.d. \\
\hline NU44 & Pestalotiopsis portugalica & intertidal zone & Colpomenia & n.d. \\
\hline NU1 & Pestalotiopsis sp & outdoor tank & sediment & n.d. \\
\hline NU25 & Phacidium sp. (WJL-2020c) & outdoor tank & surface water & n.d. \\
\hline NU43 & Phoma moricola & intertidal zone & Fushitsunagia & n.d. \\
\hline NU35 & $\begin{array}{l}\text { Pithomyces chartarum or } \\
\text { Pseudopithomyces palmicola or } \\
\text { Leptosphaerulina chartarum }\end{array}$ & intertidal zone & Lomentaria & n.d. \\
\hline NU50 & $\begin{array}{l}\text { Pyrenochaetopsis } \\
\text { (likely P. microspore, P. poae, or P. } \\
\text { aff. melioloides) }\end{array}$ & intertidal zone & Undaria & n.d. \\
\hline NU68 & $\begin{array}{l}\text { Rhodotorula babjevae (or } R \text {. } \\
\text { glutinis) }\end{array}$ & water at pier tip & surface water & \\
\hline
\end{tabular}


bioRxiv preprint doi: https://doi org/10.1101/2021.05.16.444389; this version posted May 17, 2021. The copyright holder for this preprint (which was not certified by peer review) is the author/funder, who has granted bioRxiv a license to display the preprint in perpetuity. It is made available under aCC-BY-NC 4.0 International license.

\begin{tabular}{|l|l|l|l|l|l|}
\hline NU17 & Simplicillium lanosoniveum & buoy at pier & $\begin{array}{l}\text { Polysiphonia OR } \\
\text { Melanothamnus }\end{array}$ & n.d. \\
\hline NU58 & Sphaerulina rhabdoclinis & intertidal zone & Champia & & \\
\hline NU70 & Sphaerulina sp. & intertidal zone & Fushitsunagia & & \\
\hline NU72 & Trichoderma atroviride & intertidal zone & Spatoglossum & & n.d. \\
\hline NU23 & Umbelopsis isabellina & outdoor tank & surface water & n.d. \\
\hline NU31 & Ustilago sp. & outdoor tank & surface water & & \\
\hline NU63 & Unclear & intertidal zone & Colpomenia & & n.d. \\
\hline NU30 & Unclear & outdoor tank & surface water & & \\
\hline NU74 & $\begin{array}{l}\text { Unclear } \\
\text { possibly Didymosphaeriaceae) }\end{array}$ & water at pier tip & surface water & n.d. \\
\hline
\end{tabular}

407

*1 Comparison with the fungal list of Mitchison-Field et al. (2019)

same species identified

same genus, but not species, identified

unidentified genus

\section{*2 Division type}

budding, site fixed

budding, site variable

density-dependent

multiple fissions

rod shaped, budding 
bioRxiv preprint doi: https://doi.org/10.1101/2021.05.16.444389; this version posted May 17, 2021. The copyright holder for this preprint (which was not certified by peer review) is the author/funder, who has granted bioRxiv a license to display the preprint in perpetuity. It is made available under aCC-BY-NC 4.0 International license.

\section{Figure 1}

A
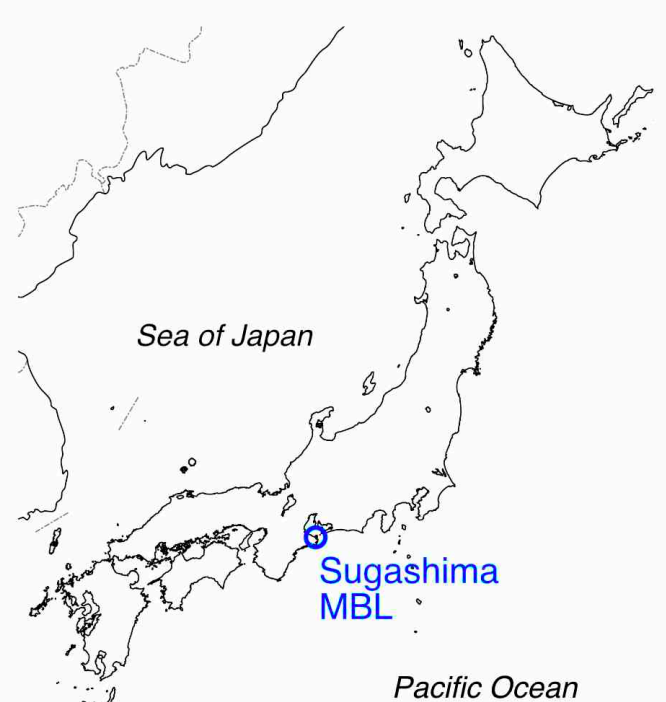

$\because$

Pacific Ocean

$\$$

D

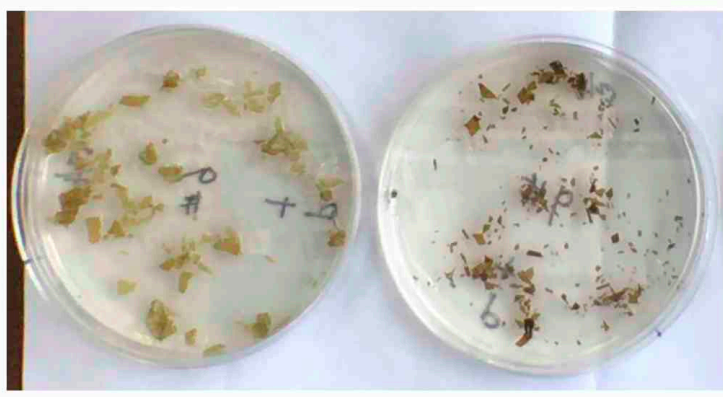

E

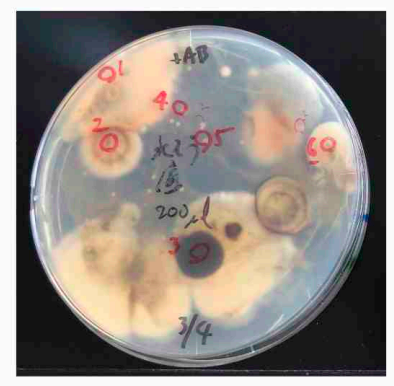

$\mathrm{F}$
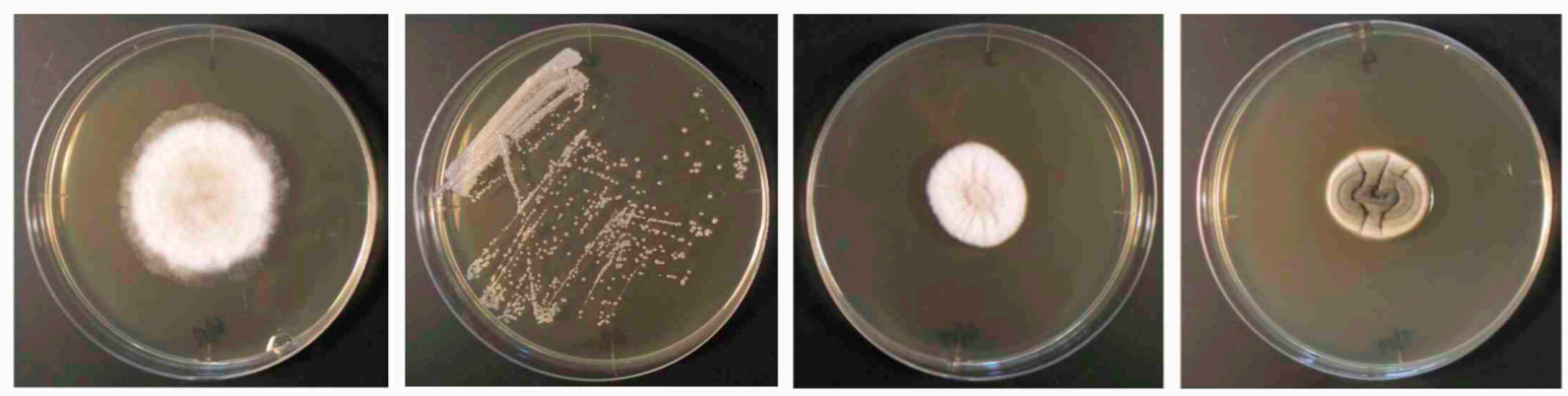

Figure 1. Collection of marine fungi from surface ocean water, sediment, and seaweeds

(A) Location of Sugashima Marine Biological Laboratory (NU-MBL). (B) Surface ocean water was obtained at the pier (green), whereas seaweeds were collected at the intertidal zone (magenta). (C) Outdoor tank at NU-MBL which has a continuous flow of unfiltered sea water. The sediment and surface water were the sources of marine fungi. (D) Severed seaweeds on the fungal medium plate. Several fungal colonies grew after several days. (E) Examples of fungal colonies on the plate (sediment sample). Each colony was marked and subjected to genotyping PCR and transfer to a fresh plate. (F) Examples of fungal colonies on YPD plates (NU1 - 4). Filamentous fungi were inoculated onto the centre of the plate, whereas yeasts were streaked. The diameter of the plates in this figure is $9 \mathrm{~cm}$. 


\section{Figure 2}

\section{A}

Metschnikowia bicuspidata (variable budding site)

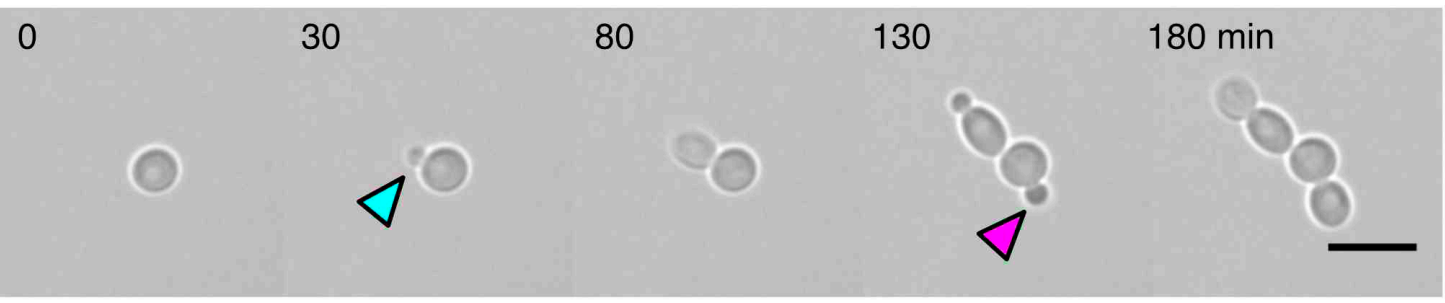

Others: Candida sake, Kluyveromyces nonfermentans, Meyerozyma guilliermondii

\section{B}

Cystobasidium slooffiae (fixed budding site)

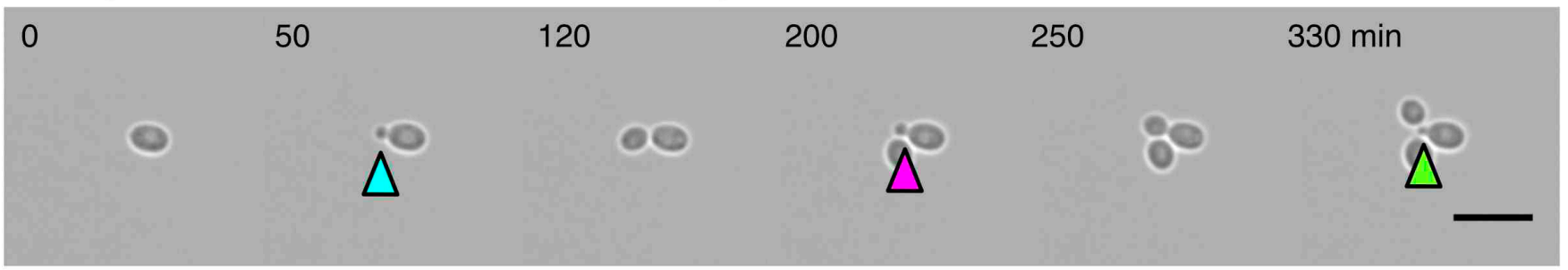

Others: Filobasidium magnum, Filobasidium sp., Rhodotorula sp.

Figure 2. Budding yeast has either a fixed or variable budding site

(A) S. cerevisiae-type budding yeast, where a bud emerges at seemingly random sites on the round mother cell. (B) The budding site is fixed at one site of the mother cell. Blue arrows, initially emerged bud; magenta arrow, second bud; green arrow, third bud. Scale bars, $10 \mu \mathrm{m}$. 
bioRxiv preprint doi: https://doi.org/10.1101/2021.05.16.444389; this version posted May 17,2021 . The copyright holder for this preprint (which was not certified by peer review) is the author/funder, who has granted bioRxiv a license to display the preprint in perpetuity. It is made available under aCC-BY-NC 4.0 International license.

\section{Figure 3}

A

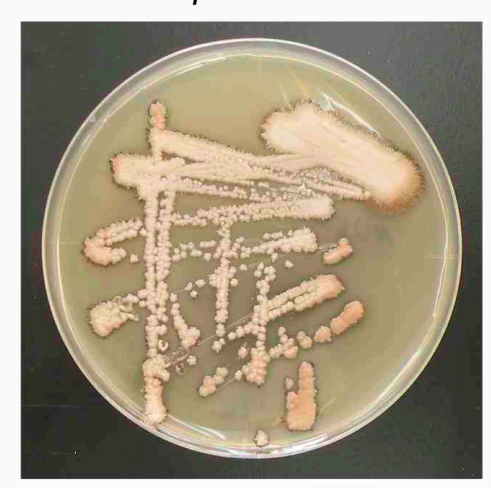

B

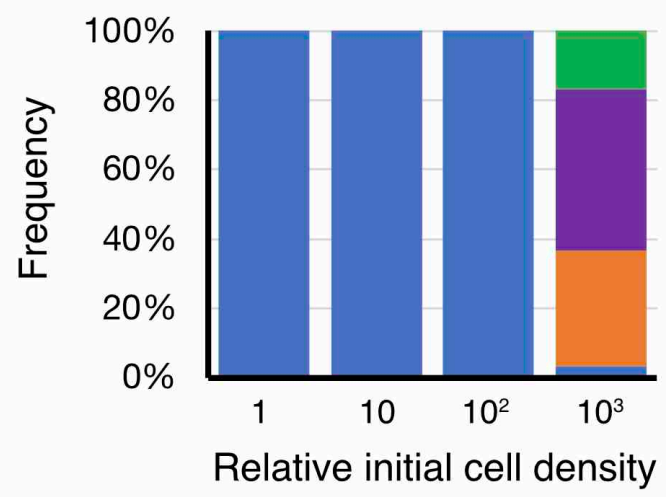

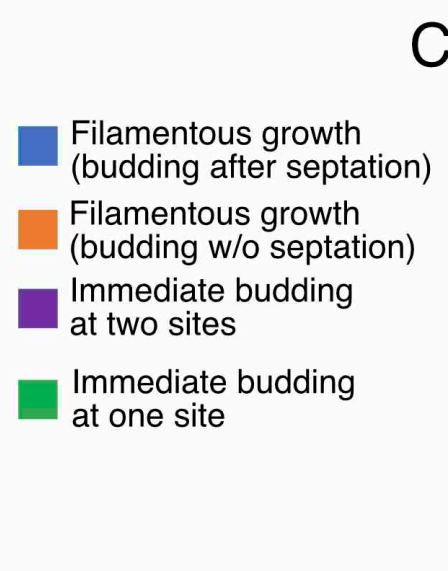
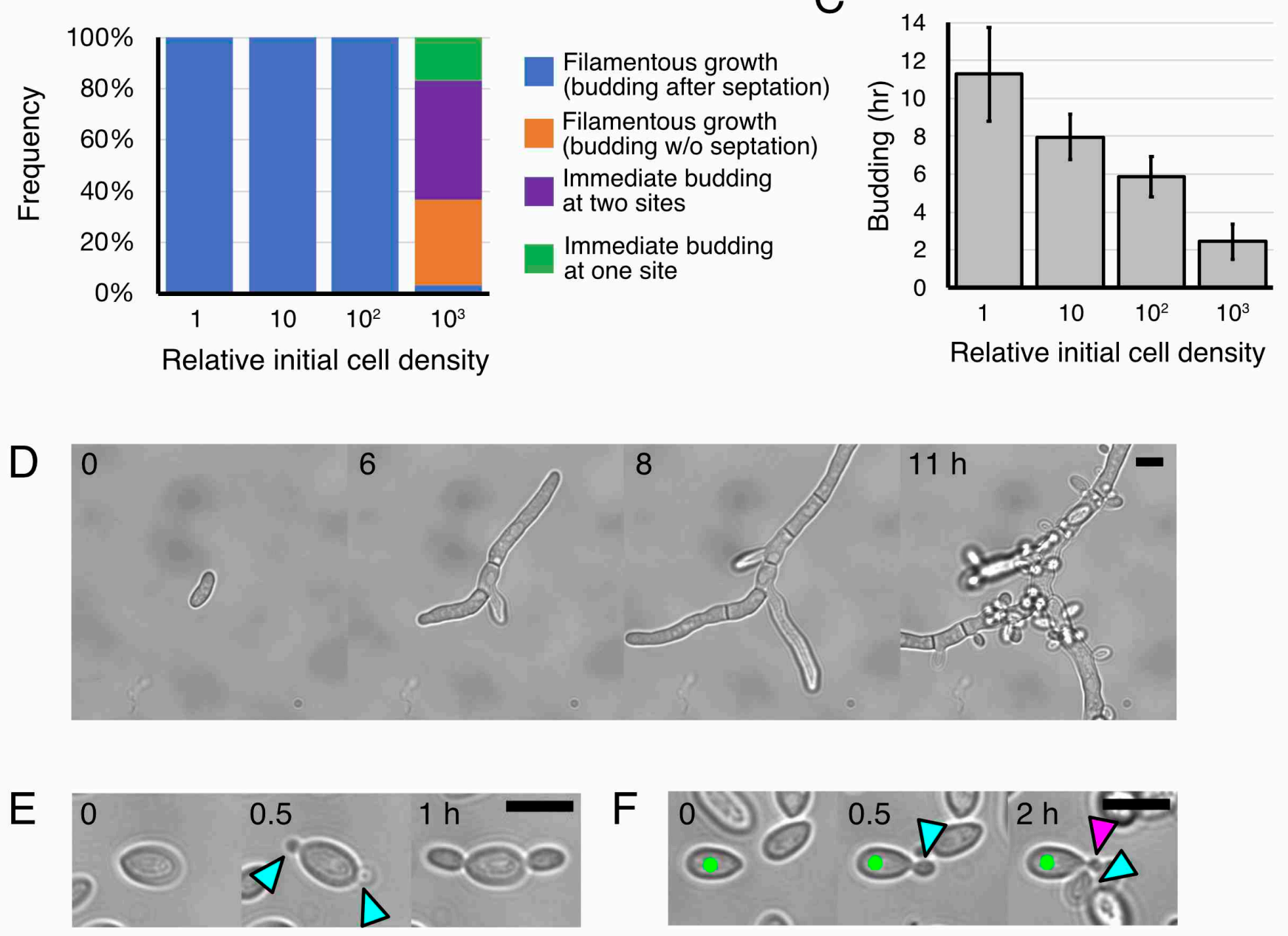

Figure 3. Division pattern variation in the black yeast Aureobasidium pullulans

(A) A. pullulans colonies. The peripheries of the colonies turned brown after prolonged storage at $4{ }^{\circ} \mathrm{C}$ (fresh colonies are uncoloured). (B) Four distinct bud formation patterns dependent on the initial cell density. Saturated cultures were diluted at four different concentrations, and the growth and budding style was assessed ( $\mathrm{n}=7,18$, 25,30 [left to right]). (C) Timing of bud emergence after a cell started to grow in a filamentous manner $( \pm$ SD) ( $n$ $=7,18,25,11$ [left to right]). (D) Filamentous growth with occasional septation and branching, followed by budding from various sites on the filament. This mode of growth/budding was dominant when the initial cell density was low. (E, F) Immediate budding without apparent cell growth or septation. Two buds simultaneously emerged at two opposite sites in (E), whereas two buds sequentially emerged at one site of the mother cell in (F). Blue arrows, initially emerged buds; magenta arrow, second bud; green, mother cell. Scale bars, $10 \mu \mathrm{m}$. 
bioRxiv preprint doi: https://doi.org/10.1101/2021.05.16.444389; this version posted May 17, 2021. The copyright holder for this preprint (which was not certified by peer review) is the author/funder, who has granted bioRxiv a license to display the preprint in perpetuity. It is made available under aCC-BY-NC 4.0 International license.

\section{Figure 4}

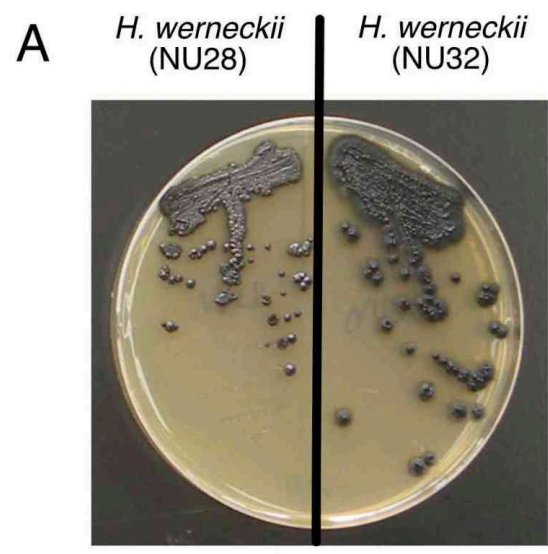

B

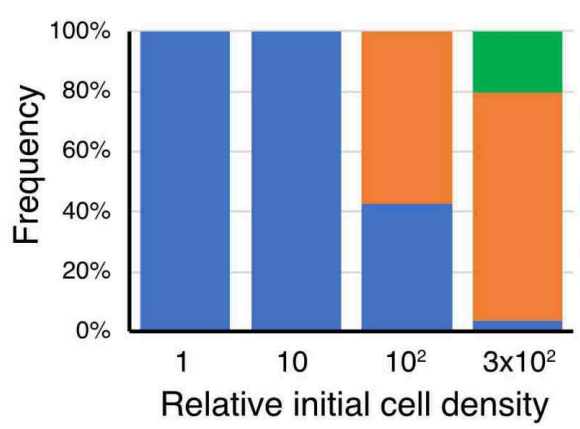

Multiple septations

Septation, then budding

Immediate budding

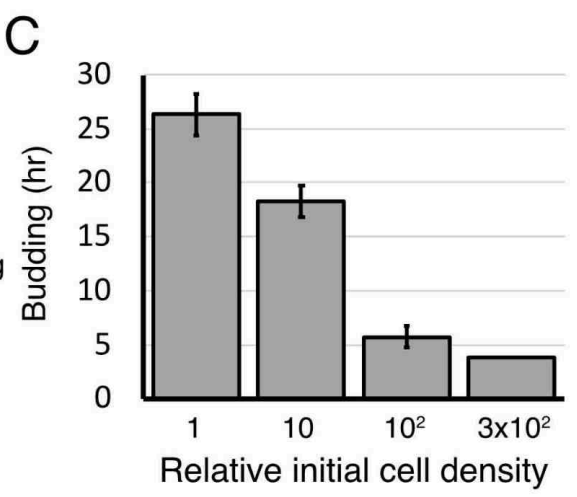

D

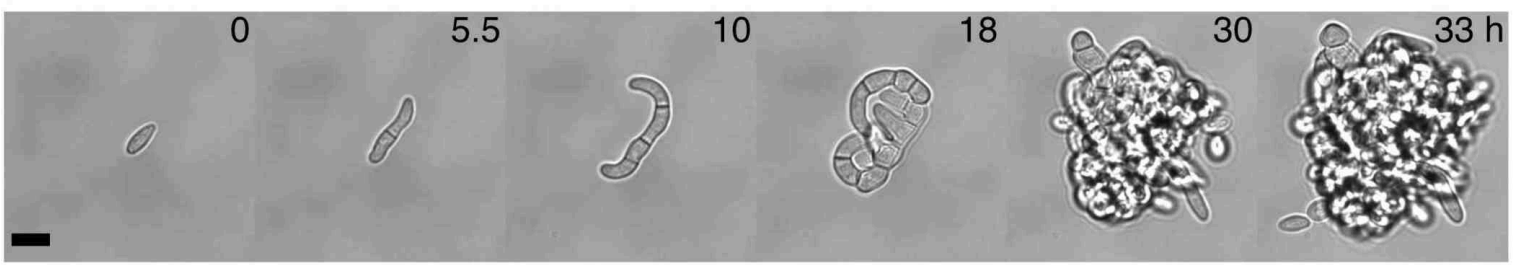

E

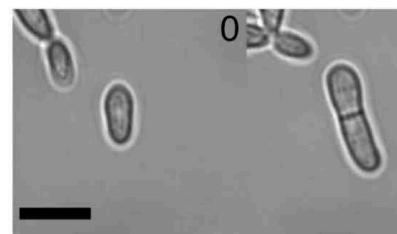

5.5
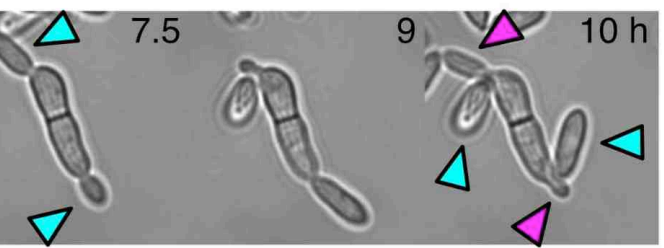

$\mathrm{F}$
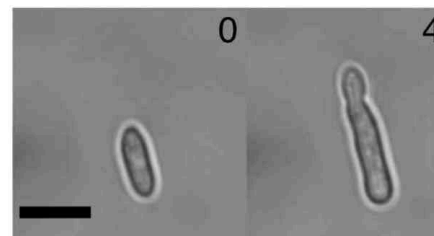

4.5

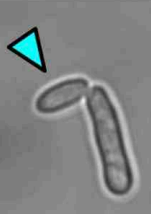

5.5

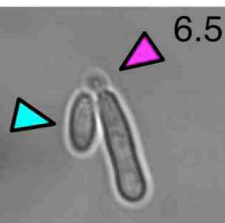

Figure 4. Division pattern variation in the black yeast Hortaea werneckii

(A) Colonies of two H. werneckii strains, which had different growth rates. (B) Three distinct bud formation patterns dependent on the initial cell density. Saturated cultures were diluted at four different concentrations, and the growth and budding style was assessed ( $\mathrm{n}=19,11,28,54$ [left to right]). (C) Timing of bud formation after the first septation $( \pm \mathrm{SD})(\mathrm{n}=19,11,12$, 2 [left to right]). Because the sample size was low, SD was not provided in the condition with the highest density. (D) Filamentous growth with septation and branching, followed by budding from various sites on the curved filament (a released bud is seen at lower-left corner at $43 \mathrm{~h}$ ). This mode of growth/ budding was dominant when the initial cell density was low. (E) Elongation, septation, followed by budding. Multiple buds sequentially emerged from a "mother" cell that had undergone septation. This mode of septation/ budding was dominant when the initial cell density was high. (F) Immediate budding without septation. Multiple buds sequentially emerged from a "mother" cell. Blue and magenta arrows indicate the first and second buds, respectively. Scale bars, $10 \mu \mathrm{m}$. 
bioRxiv preprint doi: https://doi.org/10.1101/2021.05.16.444389; this version posted May 17, 2021. The copyright holder for this preprint (which was not certified by peer review) is the author/funder, who has granted bioRxiv a license to display the preprint in perpetuity. It is made available under aCC-BY-NC 4.0 International license.

\section{Figure 5}

\section{A black yeast "NU30"}

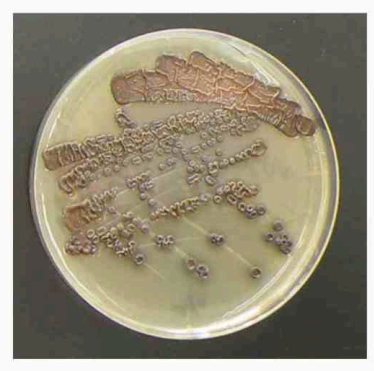

B
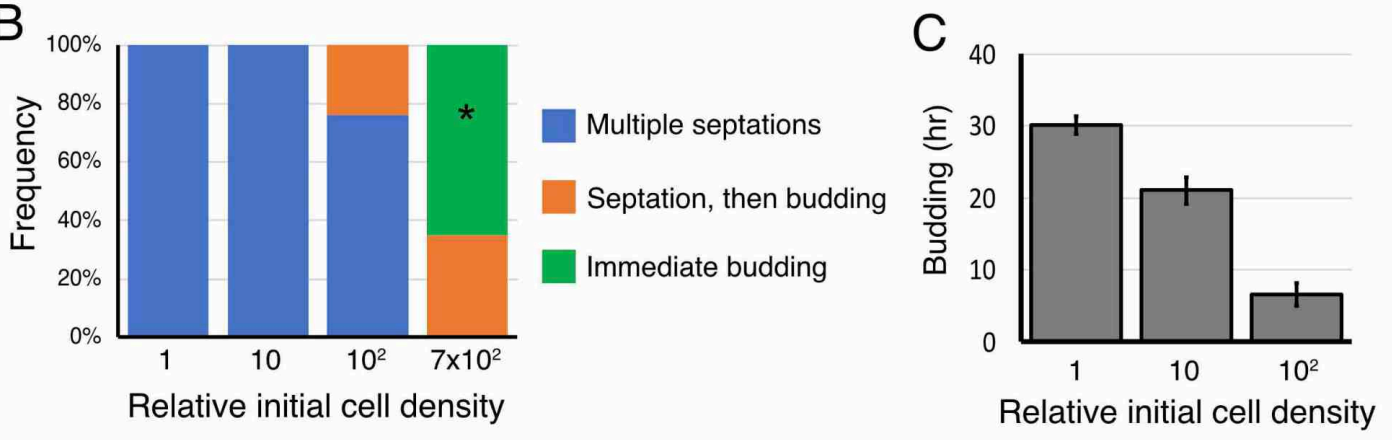

D

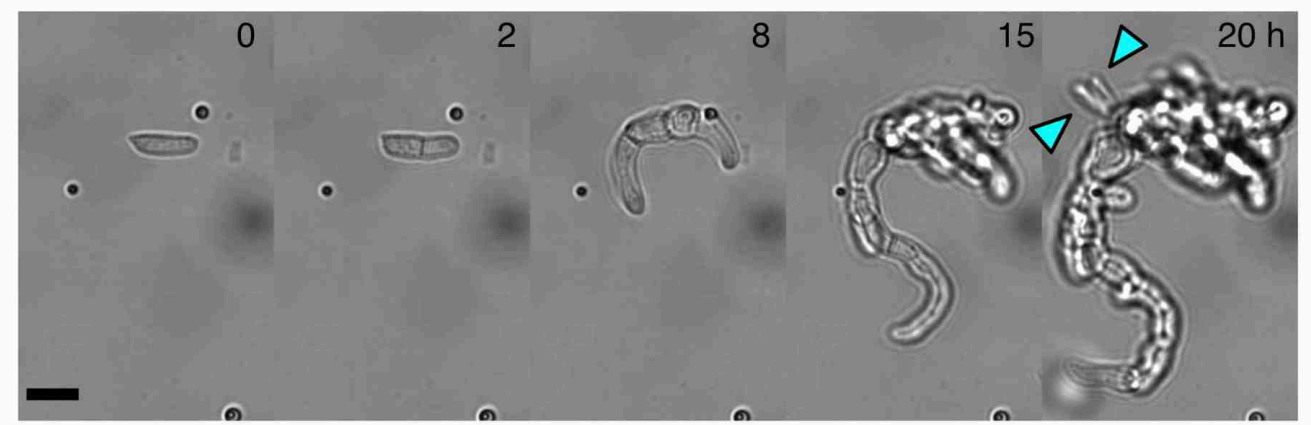

$\mathrm{E}$

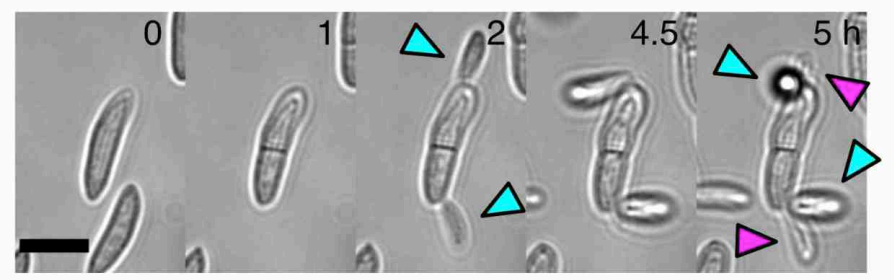

$\mathrm{F}$

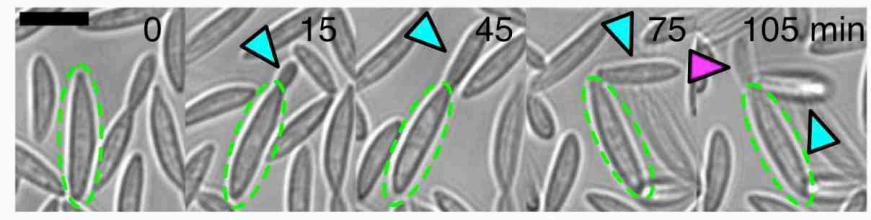

Figure 5. Division pattern variation in an unidentified black yeast species "NU30"

(A) Colonies of NU30. Each colony turned dark brown after prolonged storage at $4{ }^{\circ} \mathrm{C}$ (fresh colonies were uncoloured). (B) Three distinct bud formation patterns dependent on the initial cell density. Saturated cultures were diluted at four different concentrations, and the growth and budding style was assessed $(\mathrm{n}=12,12,25,37$ [left to right]). Asterisk: the frequency of immediately budding cells was underestimated, as many cells did not stick to the glass and were hard to count, whereas all the cells that underwent septations were immobile and countable. (C) Timing of bud formation after the first septation $( \pm \mathrm{SD})$ for the cells that formed multiple septations $(\mathrm{n}=12,12$, 19 [left to right]). (D) Filamentous growth with septation and branching, followed by budding from various sites on the curved filament $(20 \mathrm{~h}$ ). This mode of growth/budding was dominant when the initial cell density was low. (E) Single septation, followed by budding. Multiple buds sequentially emerged from a "mother" cell that had undergone septation. (F) Immediate budding without septation. Multiple buds sequentially emerged from the "mother" cell (green). This mode of budding was dominant when the initial cell density was high. Blue and magenta arrows indicate the first and second buds, respectively. Scale bars, $10 \mu \mathrm{m}$. 
bioRxiv preprint doi: https://doi.org/10.1101/2021.05.16.444389; this version posted May 17, 2021. The copyright holder for this preprint (which was not certified by peer review) is the author/funder, who has granted bioRxiv a license to display the preprint in perpetuity. It is made available under aCC-BY-NC 4.0 International license.

\section{Figure 6}

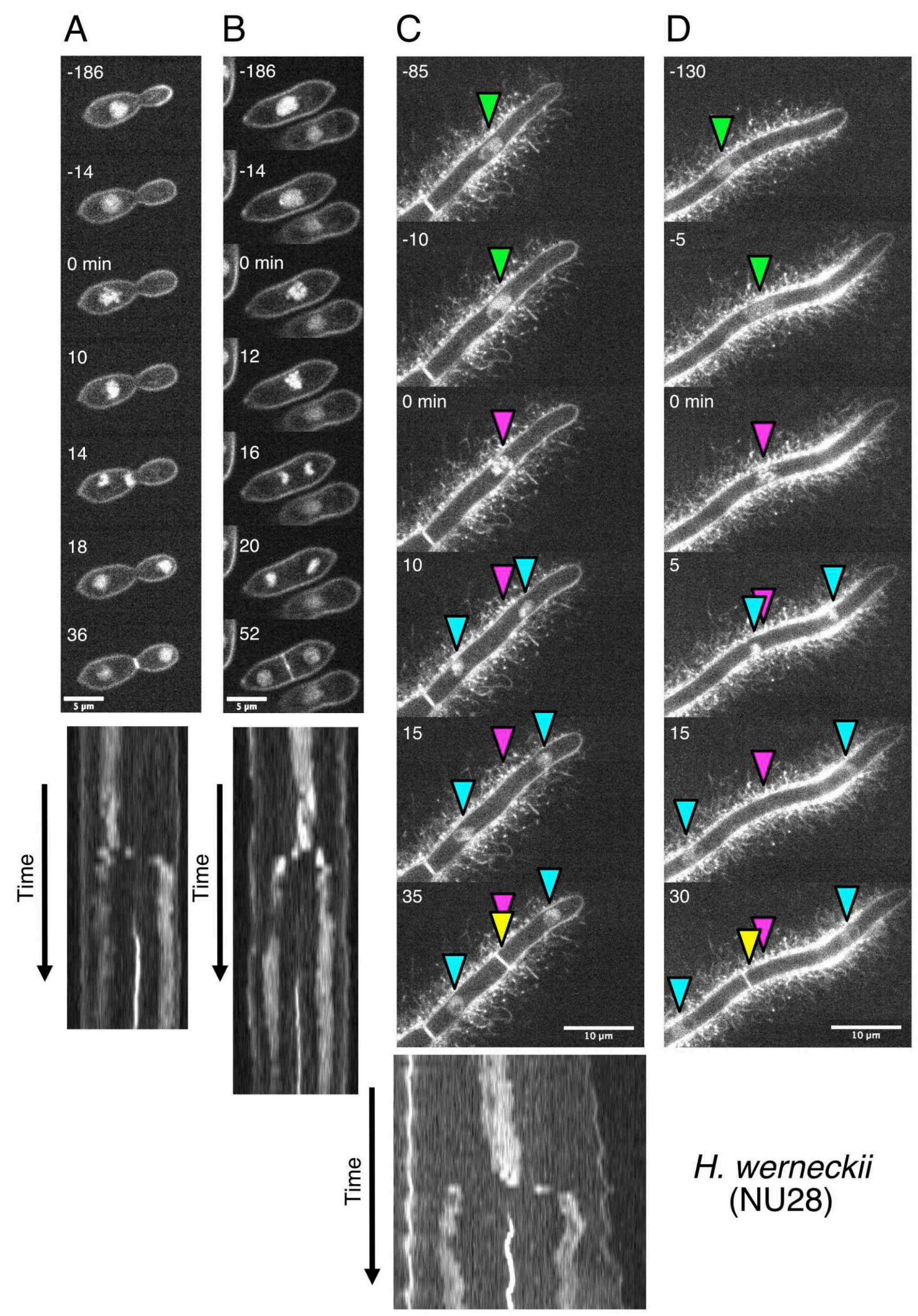

Figure 6. Nuclear dynamics in $\boldsymbol{H}$. werneckii

(A) Nuclear dynamics during budding-type cell division. The corresponding kymograph is shown at the bottom. Time 0 indicates mitotic entry. (B) Nuclear dynamics during fission-type cell division. The corresponding kymograph is shown at the bottom. Time 0 indicates mitotic entry. (C, D) Nuclear dynamics in tip-growing cells. Green arrowheads, interphase nuclei; magenta, position of condensed chromosomes at the mitotic entry; blue, sister chromatids/nuclei; yellow, septum. Septum was formed at the site of mitotic chromosomes in (C), whereas it was deviated in (D). Segregation of sister chromatids is asymmetric relative to the metaphase chromosome. The corresponding kymograph is shown at the bottom. 